
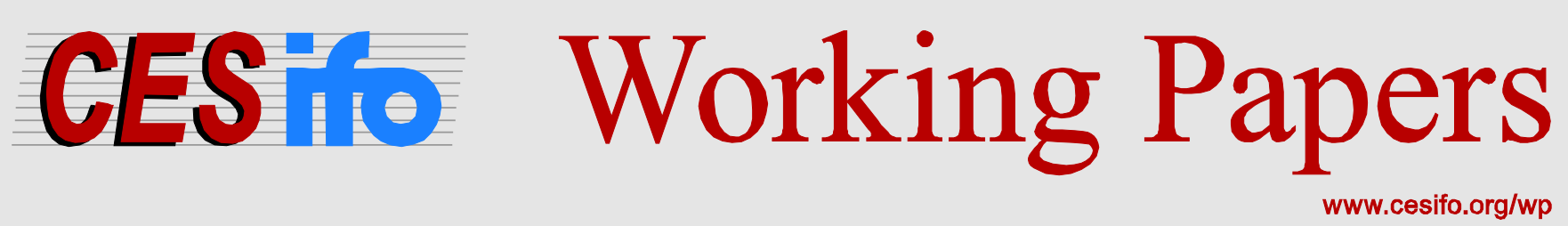

\title{
Gender, Access to Finance, Occupational Choice, and Business Performance
}

\author{
Nelli S. Gazanchyan \\ Nigar Hashimzade \\ Yulia Rodionova \\ Natalia Vershinina
}

\section{CESIFO WORKING PAPER NO. 6353}

CATEGORY 4: LABOUR MARKETS

FEBRUARY 2017

An electronic version of the paper may be downloaded

- from the SSRN website:

- from the RePEc website:

- from the CESifo website:

WWW.SSRN.com

www.RePEc.org

www.CESifo-group.org/wp 


\title{
Gender, Access to Finance, Occupational Choice, and Business Performance
}

\begin{abstract}
We present a theoretical and empirical analysis of the links between the gender of an entrepreneur, access to finance, occupational choice, and business performance. Our theoretical model predicts that, when lenders discriminate against women entrepreneurs, the average entrepreneurial skill of women who become entrepreneurs or enter paid employment as managers is higher than that of their men counterparts. This suggests that the firms owned or managed by women should perform better than the firms owned or managed by men, ceteris paribus. We find empirical support for the assumptions and the predictions of our model using firm-level data for 28 emerging economies in Europe and Asia; the effect is especially strong in the small and medium enterprises, possibly, because in large firms borrowing is a less essential source of finance. An important policy implication of our findings is that discrimination in the capital market spills over to the labour market, leading to the distortion of occupational choice and inefficiency in allocation of physical and human resources.
\end{abstract}

JEL-Codes: J240, J710.

Keywords: occupational choice, discrimination, finance, gender, small and medium enterprises.

\author{
Nelli S. Gazanchyan \\ Department of Sociology \\ Moscow University of Humanities \\ 5 Yunosti St. \\ Moscow / Russia \\ og.nelli@gmail.com \\ Yulia Rodionova \\ Faculty of Business and Law \\ Leicester Business School \\ De Montfort University, The Gateway \\ United Kingdom - Leicester, LE1 9BH \\ yrodionova@dmu.ac.uk
}

Nigar Hashimzade*

Department of Economics and Finance

Durham University Business School

Millhill Lane

United Kingdom - Durham DH1 3LB

nigar.hashimzade@durham.ac.uk

Natalia Vershinina

Birmingham Business School

University of Birmingham

Edgbaston

United Kingdom - Birmingham, B15 2TT

n.a.vershinina@bham.ac.uk

*corresponding author 


\section{INTRODUCTION}

The analysis of the effect of the gender of business owner and/or its senior manager on business performance has been a growing field in the economics and the entrepreneurship literature (Chaganti and Parasuraman,1996; Carter, et al, 2007; Coleman, 2007, Marlow and McAdam, 2013, Robb and Watson, 2012). A number of explanations of the difference in performance, such as gender discrimination in the labour and capital markets (e.g., Sabarwal and Terrell, 2008; Muravyev et al., 2009), differing degree of risk aversion of women and men (Jianakoplos and Bernasek, 2007), or their preferences for competitive behaviour (Gneezy et al., 2003; Croson and Gneezy, 2009), have been proposed in the literature; however, the empirical studies have yielded rather mixed results.

In this paper, we contribute to the literature by approaching the issue from a different angle. We start from the assumption that lenders discriminate against women and analyse a link between capital market and the labour market. Consider the situation when lenders charge prohibitively high interest rates or impose strict collateral requirements for women borrowers, so that firms owned by women are faced with a higher cost of capital. Then, on average, a female entrepreneur is expected to be more successful compared to a male entrepreneur. Furthermore, assuming that those who were denied loans enter paid high-skill employment, there are also implications for the distribution of entrepreneurial skill in the managerial jobs.

We construct a theoretical model, along the lines of Coate and Tennyson (1992), according to which discrimination against women business owners in the capital market results in a higher conditional average of the entrepreneurial skill of women business owners and women senior managers in comparison to that of the male owners and managers. If entrepreneurial skill of the owner or manager of a firm is one of the factors contributing to that firm's performance, the model suggests that, ceteris paribus, businesses owned and/or managed by women should perform better than businesses owned and/or managed by men.

We find empirical support both for the assumption about discrimination and the prediction about business performance using the 2009 wave of the Business Environment and Enterprise Performance Survey (BEEPS), a firm-level data set for countries in Eastern Europe and Central Asia, with the focus 
on small and medium entrerprises (SME). We chose these countries because we expect gender discrimination there to be stronger than in the developed countries, because of the weaker institutions and regulations preventing open or hidden discrimination. For the data analysis we use the ordinary least squares (OLS) regression, as a benchmark, the two-stage least squares (TSLS) with a set of instruments, and the propensity score matching technique, to control for potential endogeneity; we employ Heckman's procedure to account for selection. First, we test whether women SME owners are subjected to discrimination by lenders in the capital market; in particular, we test whether women are more likely than men to face prohibitively high interest rates or prohibitively strict collateral requirements, and whether restricted access to finance is viewed more often by women than by men as an obstacle to business. Second, we test whether there is a positive effect of the female gender of a company's owner and/or senior manager on that company's performance, as measured by sales, profit, and profits per unit of sales.

Our study has important policy implications. In the presence of discrimination of women in the capital market fewer women than men with similar entrepreneurial skills become business owners, if they are unable to obtain sufficient funds to start or expand their business, in order to realize their entrepreneurial potential. This distortion may lead to an individual welfare loss for aspiring women entrepreneurs; it also creates a social inefficiency by distorting allocation of physical and human capital. Hence, eliminating unequal treatment of men and women in the capital market, in addition to an improvement in allocation of capital resources, will remove the distortion in occupational choice and improve allocation of human resources.

\section{EMPIRICAL AND THEORETICAL LITERATURE}

Discrimination, and, in particular, discrimination in the labour market, has been studied extensively in economic theory, beginning with the seminal work by Becker (1971) and Arrow (1973). The distinction is drawn between the preference discrimination, whereby employers, for example, have preferences favouring one group of agents over another, and the statistical discrimination, whereby the "testing error" committed by employers is higher for one group than for the other (Phelps, 1972). For example, Blanchflower et al. (2003) found evidence of discrimination of black business owners in the small 
business loan market in the United States. Furthermore, the two types of discrimination can be endogenously linked: as Coate and Loury (1993) show, when the quality, or skill, of a potential employee is determined by this individual's rational choice of a costly action, such as investment in human capital, the difference in quality between the groups, as perceived by the discriminating employer when information is asymmetric, may become self-fulfilling.

The link between the preference discrimination and the statistical discrimination can also emerge across different markets. As demonstrated by Coate and Tennyson (1992), preference discrimination in the labour market can spill over to the capital market, where it induces statistical discrimination. This, in turn, affects the occupational choice of individuals belonging to the group subjected to discrimination and results in an inefficient allocation of physical and human resources. However, the reverse channel, that is, a distortion of the occupational choice generated by preference discrimination in the capital market has not received attention in the literature.

In this paper we fill an important gap in the literature on discrimination by considering this reverse channel, as in the current economic and political environment the discrimination in the capital market is easier to overlook than discrimination in the labour market. While there is still strong evidence of a "glass ceiling" for women, especially in high-skill jobs (e.g., Equality and Human Rights Commission, 2011), in recent decades in the Western developed countries there has been a push towards reducing gender discrimination in the workplace through legislation and the scrutiny of hiring and other personnel procedures. At the same time, similar monitoring of private lenders in the capital market is virtually nonexistent.

There are a number of empirical studies on the extent to which women-owned businesses face discrimination in the credit markets. The findings are rather mixed. Coleman (2000) argues that businesses managed by women are less attractive to banks because they are typically small and are considered to be riskier ventures: the banks prefer to finance larger projects that are already established, - a preference that works in favour of men. Because of this adverse selection, the average size of the businesses run by women is lower, leading to a self-reinforcing discrimination mechanism (Scalera and Zazzaro, 2001). Also, according to Moro et al. (2014), banks tend to charge lower interest 
rates if the loan manager perceives the entrepreneur to be competent, which can, once again, work against female entrepreneurs.

Evidence of gender stereotyping and prejudices that bank employees might have against women entrepreneurs was revealed in an earlier study by Carter et al. (2007). The authors find that, when evaluating loan applications, bank lenders prioritize comprehension and commitment for applications from female borrowers, whereas male borrowers are evaluated on integrity, capability, and marital status. In addition, the operative processes used by male and female loan officers to negotiate loan applications appeared to differ: while female loan officers focus on procedural and business elements of the loan, male loan officers give priority to the individualized decision making and the internal negotiation with the bank. The authors conclude that "gender remains an important but often hidden variable within bank lending." (Carter et al. 2007, p. 440.)

However, Robb and Wolken (2002), using the data for the United States, demonstrate that when the characteristics of the firm and its owner are taken into account, women have equal access to credit. Similarly, Fraser (2009) finds no evidence of gender discrimination in the UK market for small business finance. A survey of 2,000 Dutch entrepreneurs by Verheul and Thurik (2001), for example, found that most differences in the use of starting capital by male and female entrepreneurs were explained by "indirect" effects (size, age, sector); however, some residual, "direct" gender effects survived; similar results were reported by Brush et al. (2002). Wu and Chua (2012) find evidence of a second-order gender effect in U.S. small business borrowing cost in a study of 1,577 small businesses from the 2003 National Survey of Small Business Finances by the Federal Reserve Board. According to their study, lenders charge female sole proprietorships an average of 73 basis points higher than male sole proprietorships, - after organization and economic factors are taken into account. ${ }^{5}$

Some other studies have found that structural disparities cannot account for all the gender differences in financing patterns. For example, according to Buttner and Rose (1988), women are usually less satisfied than men with the relationship they have with their bank. Fairlie and Robb (2008)

\footnotetext{
${ }^{5}$ The authors are grateful to the anonymous reviewer of an earlier version of this paper for suggesting this reference.
} 
reported that businesses managed by women are both younger and smaller than those run by men and have slower growth rates. Banking conditions would, therefore, be the result of rational banking behaviour when faced with riskier ventures.

It also seems that women experience greater difficulty in providing collateral. Women, who are more likely to work part-time and earn less than men, are therefore less likely to accumulate enough resources in the form of personal savings, that could be used as a collateral (Marlow and Patton, 2005). For these reasons, the lack of personal funds puts women at a disadvantage when starting up business: their personal financial input is limited and is often insufficient as collateral that could strengthen the loan relationship.

Gender stereotypes are still at play in banking relationships with women who are asked to provide higher collateral and upon whom stricter credit limits are imposed (Bellucci et al., 2010) and higher interest rates are charged (Coleman, 2000). Roper and Scott (2009) in their study using Global Entrepreneurship Monitor data for the UK have found that women are about $7.4 \%$ more likely to perceive financial barriers to business start-up than men. However, as Sabarwal and Terrell (2008) point out, "it is not clear whether [unequal access to finance] is due to discrimination on the part of the banking sector or the result of other factors," such as, potentially, institutional factors and social norms (Aidis et al., 2007).

Similarly mixed findings were reported in the research of the post-Sovet era entrepreneurship in Russia and other countries of the former Soviet Union. A study by Babayeva and Chirikova (1996) shows that in the early 1990s, that is, at the very beginning of perestroika, the distribution of the responses of the directors of non-state enterprises on the question about the means for financing of the start-up in Russia (Table 1) did not demonstrate any strong evidence of discrimination against women. However, the authors claim that the result of the survey might have been biased due to the fact that it was commissioned by the John D. and Catherine T. MacArthur Foundation, and the respondents might have wanted to show an image of correctness. Arguably, the situation has worsened in the later years, as the society in Russia faced reversal to the "traditional", more patriarchal values, which has also affected the business sphere. 


\section{[Insert Table 1 Here]}

In the Ukraine businesses run by men are more often required to pay upfront, compared to businesses run by women ( $41 \%$ against $33 \%$ ), suggesting that female entrepreneurs are trusted more and thus might enjoy more favourable conditions for obtaining credits. At the same time, between a third and a half of female entrepreneurs admitted not applying for credits because of the high interest rates, and almost one out of six female entrepreneurs admits that present requirements for a collateral are overly tight (Lavrinenko and Rudik, 2010).

Another study of the business environment in the Ukraine (Isakova et al., 2004) found that female entrepreneurs are facing a more acute problem of the start-up capital: $51 \%$ of women admit that this was the major problem in the beginning, against $37 \%$ of men. The problem with finances persists in the later years, and, although it moves in ranking to the third place, after taxes and regulations, it remains more acute for women than for men (23\% against $8 \%)$. It has been revealed that women are more wary of risk when borrowing externally: $38 \%$ of women do not apply for credit for this only reason, against $20 \%$ of men.

The Center for Study of Public Opinion (2003) survey (2003) presented responses obtained from 684 female entrepreneurs in Uzbekistan. In the opinion of $37 \%$ of the respondents, Uzbekistan has favourable conditions for business, $45 \%$ believe the conditions are not quite favourable, $15.2 \%$ find the conditions very unfavourable, and $2.8 \%$ could not decide. On another question, $58.5 \%$ believed that women do not have equal opportunities with men for entrepreneurial activity, $40.8 \%$ opposed to that, and $0.7 \%$ could not decide. The main obstacle to the development of business for women in Uzbekistan is the gender stereotypes about the roles of women and men that persist in the society (Rahimova, 2006). A more recent study also showed that in Uzbekistan female entrepreneurs find it difficult to obtain credit because of the high interest rate and lack of required collateral (Sugarova, 2012). In a comprehensive study using the 2002-2005 waves of BEEPS database, Muravyev et al. (2009) found empirical evidence of gender discrimination in the capital market in a wider set of post-Soviet countries, including Eastern Europe. 
Empirical evidence of the effect of an owner's gender upon business performance is also mixed. Some studies have shown that female ownership has a significantly negative impact on sales (Sabarwal and Terrell, 2008) and on profits (Robb and Wolken, 2002; Bosma et al., 2004). An interesting study by Powell and Eddleston (2008) looked at the business performance and business owner's satisfaction; in their survey of 201 business owners firms owned by men performed better than firms owned by women (relative to competitors and as measure by sales), but male owners were less satisfied by their business performance, compared to women. According to the study, female owners place less value on the success and on the fluctuations in business performance and in sales than male owners. Other authors find no effect of the owner's gender on the firm's performance (Watson, 2002; Johnsen and McMahon, 2005; Kepler and Shane, 2007). Furthermore, Coleman (2007) finds that women-owned firms have significantly higher annual sales growth than firms owned by men after the industry and firm size are controlled for. In a longitudinal study of over 4,000 new ventures started in the US from 2004, Robb and Watson (2012) show that there is no difference in performance between men-owned and women-owned firms, when using appropriate measures of performance (the authors used return-on-asset and Sharpe ratio, among others) and controlling for demographic differences.

In this paper we consider all of this evidence as a starting point for our empirical analysis of this specific link between the capital market and the labour market, modelled in the theoretical part of the paper. We examine two directions of gender effect, on the access to finance and on firm's performance. Thus, our study contributes to the field by analysing the effect of gender bias in lending to start-ups upon the occupational choice of potential entrepreneurs.

Among important determinants of the extent and perception of gender discrimination are the cultural and the legislative context which depend on the geographical location and political environment. For example, a survey of 583 working women in the United States, Chinese mainland, and Hong Kong SAR by Shaffer et al. (2000) has revealed differences across geographical regions in the levels of gender discrimination and in the relationships between gender evaluation and job outcomes. The choice of the data set for the test of our model was driven by the differences in institutions and regulations between the developed countries (where much of the previous research of similar issues has been 
conducted) and the developing countries of the former Soviet bloc. These countries had a different history of gender attitudes and different patterns in gender discrimination from those experienced by the developed Western countries. The differences are even more striking in the attitudes to entrepreneurship and to the place of women in business. This has been recognized in the literature: for example, Smallbone and Welter (2001a, 2001b) point to the different institutional and regulatory context and the nature of entrepreneurial activity in transition economies. The importance of gender aspect was highlighted, for example, in a cross-country study of the effect of political and regulatory environment on women versus men-owned firm entry rates by Estrin and Mickiewicz (2011): the authors find that the effect of the extent of government intervention in the economy (proxied by the size of the state sector) on the entrepreneurship rates is negative for all, but is significantly stronger for women. That is, regulatory burden weighs heavier on women-owned businesses. We anticipate that the effects of discrimination upon the occupational choice in entrepreneurship, modelled in the theoretical part, will be more pronounced in the transition economies, characterised by larger state sector, democratic institutions, and weaker regulations that would prevent open or hidden discrimination.

\section{THEORETICAL MODEL}

In this section we develop a theoretical model of occupational choice of a potential entrepreneur in the presence of discrimination in the capital market. The model is similar to the Coate and Tennyson (1992) model of discrimination in the labour market. If the availability of a loan for starting up a business is part of the occupational choice decision ${ }^{6}$, discrimination results in the distortion of the choice. Assuming that the occupational choice is linked to the distribution of entrepreneurial skill, the resulting distribution of skill conditional on the choice of occupation will be different for men and women, even if the unconditional distribution of skill is the same.

\footnotetext{
${ }^{6}$ In general, of course, an entrepreneur can finance a start-up using own savings or informal borrowing from family and friends. We control for the availability of alternative sources of finance in the empirical part of this study.
} 
Consider an economy populated by two visibly distinctive groups of agents, such as two genders. An agent chooses either to be employed or to become an entrepreneur (a business owner). To become an entrepreneur an agent must borrow in the credit market. In the labour market there are two types of job, skilled (managerial level) and unskilled (regular employees). Each agent is capable of doing the unskilled job, but only high-skilled agents can do the skilled job. The fraction of skilled agents is the same in the two groups. Each worker is paid their (constant) marginal product of labour. We assume that all workers are correctly assigned to jobs according to their skill. ${ }^{7}$

In our model, all skilled workers possess some level of entrepreneurial skill, quantified as the probability $p$ of success of a potential undertaking. Thus, each skilled worker is characterized by probability $p$ of entrepreneurial success, drawn from a (continuous) distribution, assumed to be the same for all skilled workers. In other words, gender groups on the aggregate do not differ in their entrepreneurial abilities. For all unskilled workers, we are making the simplifying assumption that $p=0$. A worker's entrepreneurial skill is their private information and it is not known to any other party. For each worker an investment of capital $K$ in a project results in a gross return of either $R>0$ with probability $p$, or zero with probability $1-p$. The entire amount of investment must be borrowed from a competitive credit market. The lenders observe the gender of a borrower and know the distribution of the probability of success.

The workers are risk-neutral, and therefore, taking the interest rate, $r$, and the wage rate, $w$, as given, a worker with probability of entrepreneurial success $p$ chooses to become an entrepreneur if, and only if, the expected return on the investment project is greater than the wage, $p[R-(1+r) K] \geq w$. All workers with $p<p^{*}$, where

$$
p^{*}(r, w)=\frac{w}{R-(1+r) K}
$$

\footnotetext{
${ }^{7}$ The main result will still hold if there is imperfect information in the labour market, so that a skilled (unskilled) worker is incorrectly assigned to an unskilled (skilled) job with some positive probability, provided that this probability is not too high.
} 
enter paid employment. This is shown by the workers curve (curve $W C$ in Fig. 1) that traces out the cut-off probability $p^{*}(r, w)$. This curve is increasing and convex in $r$, and it is higher for the higher values of $w$, so that the higher are the interest rate and the wage, the more people will join paid employment. ${ }^{8}$

A non-discriminating lender breaks even when lending to a borrower with wage $w$ if

$$
E\left[p \mid p \geq p^{*}(r, w)\right](1+r) K=(1+\rho) K
$$

where $\rho$ is the risk-free interest rate. This condition defines a downward sloping lenders curve $p^{*}(r, w)$. The equilibrium in the credit market without discrimination is defined as the interest rate and the cut-off probability pair, $\left(r^{*}, p^{*}\right)$, such that the lenders make zero profit from lending to either group, that is,

$$
\left(1+r^{*}\right) \mathrm{E}\left[p \mid p \geq p^{*}\left(r^{*}, w\right)\right]=1+\rho .
$$

Suppose, however, that the lenders discriminate against women, for example, by requiring from them a higher expected return than from men. In such a situation the lenders' behaviour is described by two curves, $\left(1+r_{M}^{*}\right) \mathrm{E}\left[p \mid p \geq p^{*}\left(r_{M}^{*}, w\right)\right]=1+\rho_{M}$ (curve $L C_{M}$ in Fig. 1$)$ and $\left(1+r_{F}^{*}\right) \mathrm{E}\left[p \mid p \geq p^{*}\left(r_{F}^{*}, w\right)\right]=$ $1+\rho_{F}$ (curve $L C_{F}$ in Fig. 1), with $\rho_{F}>\rho_{M}$.

\section{[Insert Fig. 1 Here]}

One can see that, given $\rho_{F}>\rho_{M}$, the $L C_{M}$ curve lies above the $L C_{F}$, and in equilibrium the interest rate charged to female borrowers is higher than that charged to male borrowers. Thus, the firms owned by women are faced with a higher cost of capital. Furthermore, the probability of success of the marginal female borrower is higher than that of the marginal male borrower. That is, on average, female entrepreneurs are more successful than male entrepreneurs.

Moreover, recall that the skilled agents with $p<p^{*}\left(r_{M, F}^{*}, w\right)$ are assigned to managerial jobs. If $p$ reflects the entrepreneurial abilities of a skilled worker, then the (conditional) average entrepreneurial skill of females assigned to managerial jobs is higher than that of males, and the (conditional) average entrepreneurial skill of female owners is higher than that of male owners:

$$
p^{*}\left(r_{F}\right)>p^{*}\left(r_{F}\right) \Rightarrow\left\{\begin{array}{l}
E\left[p \mid p<p^{*}\left(r_{F}^{*}, w\right)\right]>E\left[p \mid p<p^{*}\left(r_{M}^{*}, w\right)\right] \\
E\left[p \mid p>p^{*}\left(r_{F}^{*}, w\right)\right]>E\left[p \mid p>p^{*}\left(r_{M}^{*}, w\right)\right]
\end{array}\right.
$$

8 The proof is straightforward and is similar to the one in Coate and Tennyson (1992). 
Assuming that the owner's and the manager's entrepreneurial skill are among the factors enhancing the firm's performance, we would then expect that, ceteris paribus, firms with female managers perform better than firms with male managers. Similarly, women-owned firms are expected to perform better than men-owned firms, after the effect of the discrimination in the capital markets (reflected, for instance, in higher interest rate or in a more restricted access to finance) is taken into account. Our empirical analysis described in the next section appears consistent with the model predictions.

\section{EMPIRICAL STRATEGY AND DATA}

\subsection{Hypotheses}

The following assumption (Hypothesis 1) and two predictions (Hypotheses 2a and 2b) ${ }^{9}$ of our theoretical model lend themselves to an empirical test.

Hypothesis 1: Female business owners face higher interest rates and collateral requirements.

Hypothesis 2. Female senior managers (2a) and business owners (2b) have higher entrepreneurial skills than male senior managers (2a) and business owners (2b).

Because entrepreneurial skill of individual owners and managers is not recorded in the dataset (and, indeed, it is difficult to measure directly), we can instead look at some measures of business performance, such as sales or profits. If, after controlling for the usual determinants of sales or profits (such as the capital stock, labour, intermediate inputs, e.g. electricity, as well as industry and country level fixed effects), the remaining unobserved heterogeneity is due to the entrepreneurial skill of the owner or the senior manager, then the difference in performance of businesses owned or managed by men and those owned or managed by women can be, at least partly, attributed to the difference in the (conditional) average entrepreneurial skill between men and women.

\subsection{Data}

\footnotetext{
${ }^{9}$ This compact formulation of the working hypotheses was very helpfully suggested by an anonymous reviewer of an earlier version of the paper.
} 
We test the assumption and the predictions of the theoretical model using a sample of firm-level data on about 7,700 enterprises in 28 countries in Eastern Europe and Central Asia ${ }^{10}$ from the 2009 wave of the BEEPS. This dataset contains information on such firm-specific characteristics as sales, material and labour costs, fixed assets, the gender of the firm's owner (the largest owner for jointly owned firms) and of the senior manager, and the tenure (in years) of the senior manager in his or her sector. Although BEEPS data has four waves (1999, 2002, 2005, and 2009, with a panel component of 2002 - 2009), we used only the 2009 wave, as it was the only wave to provide information on the gender of the senior manager.

For the jointly-owned firms the dataset reports the gender of an individual with the largest stake in business. We have identified 69 firms where the female owner has less than 15 per cent stake in the business, of which in 38 firms the stake less than 10 per cent. These numbers represent 1.87 per cent and 1 per cent, respectively, of total number of firms where there is a female owner. Therefore, for the overwhelming majority of firms in the total sample of 3,683 firms with at least one woman owner, there is a principal owner who is a woman, with a stake of at least 15 per cent; these firms are identified as owned by women.

A note of caution is needed about the quality of the data on the fixed assets, or the capital stock $(K)$, and cost of materials $(M)$, for which observations are missing in about half of the sample. We circumvented this problem by imputing both $K$ and $M$ by the corresponding country-industry averages. However, our main results are robust to the inclusion of all input variables into the estimated equations.

10 The BEEPS dataset includes 29 countries: Albania, Armenia, Azerbaijan, Belarus, Bosnia and Herzegovina, Bulgaria, Croatia, Czech Republic, Estonia, Georgia, Hungary, Kazakhstan, Kosovo, Kyrgyz Republic, Latvia, Lithuania, FYR of Macedonia, Moldova, Mongolia, Montenegro, Poland, Romania, Russia, Serbia, Slovak Republic, Slovenia, Tajikistan, Turkey, Ukraine and Uzbekistan. We drop Turkey, the only non-post-Soviet country in the dataset, from our sample as we believe that the socio-economic and cultural environment in Turkey differs significantly from that in the countries in the post-Soviet space. 
Summary statistics for the whole sample and for the sub-samples by the gender of the owner and that of the senior manager are presented in Table 2.

\section{[Insert Table 2 Here.]}

\subsection{Results}

4.3.1. Access to finance, size of the collateral, and interest rates

For Hypothesis 1 we used the difference-in-means test and a linear regression for the variables representing access to external finance. Our results generally support the hypothesized discrimination in the capital market. The data set includes a number of questions on the access to external finance. In particular, on the question about the reason for not applying for a loan the available choices were "Interest rate is too high" and "Collateral is too high". We estimated the difference in the mean response by the gender of the business owner; the results are presented in Table 3. For the first response, chosen by 8.8 per cent of all respondents, the difference in the mean by the owner's gender is only 0.3 per cent and not significant at the 0.1 level. For the second response the difference is 0.7 per cent and is statistically significant at the 0.05 level; however, only 2.78 per cent of all respondents chose this answer.

Another question was about the access to finance as an obstacle to business, where the available choices were "not an obstacle", "moderate", "major" and "very severe obstacle". We assigned the values from 1 to 4 to these responses, respectively, and estimated the mean response separately for the firms

owned by women and by men. The results suggest that female owners are more likely to view access to finance as an obstacle to doing business; the difference between two groups is 0.04 , statistically significant at the 0.05 level.

Female business owners have to put up, on average, a 4.6 per cent larger collateral to obtain a loan, compared to male owners. However, the difference-in-means test shows that it is not significant at the 0.1 level.

We also estimated two linear regression at the firm level, with the level of interest rate in the first regression and the size of the collateral in the second regression as the dependent variable, a binary variable for the owner's gender (equal to 1 if the firm is owned by a woman and zero otherwise) as the 
explanatory variable, and a set of control variables. Following Muravyev et al. (2009), we included correction for selection on whether or not the firm needs a loan, the profit of the firm, capacity utilization, firm's age, and competition faced by the firm, as well as the industry and country fixed effects; and $\varepsilon$ is the random error. The estimated coefficient on the female owner variable was positive, meaning that, ceteris paribus, female owners face higher interest rates and higher collateral requirements, but only marginally significant. When we corrected for the sample selection of the firms that did, in fact, require a loan, using Heckman's procedure, with country and industry fixed effects along with profits and sales growth in the selection equation, the result became even less significant. ${ }^{11}$

Our results regarding higher collateral and higher interest rates for women echo those reported by Coleman (2000) and Bellucci et.al (2010); the result that women are more likely to perceive financial barriers as an obstacle to business agrees with the findings of Roper and Scott (2009).

\subsubsection{Gender Effect on Business Performance: OLS and TSLS Estimation}

Hypotheses $2 \mathrm{a}$ and $2 \mathrm{~b}$ are tested using the estimation of the production function, following Sabarwal and Terrell (2008), where the dependent variable is (the logarithm of) the firm's sales, the explanatory variables are the gender of the owner, the gender of the senior manager, and the interaction between the two, and in addition a set of control variables are included in the regressions to account for the usual factors contributing to business performance. More specifically, we estimate a Cobb-Douglas production function with pooled firm-level data:

$$
\log Y=\gamma^{O} F O+\gamma^{M} F M+\delta(F O \times F M)+\beta^{K} \log K+\beta^{L} \log L+\beta^{M} \log M++X \lambda+Z \mu+\varepsilon
$$

where $F O=1$ if the firm is owned by a woman and zero otherwise, $F M=1$ if the senior manager is a woman and zero otherwise, $K$ is the capital stock (at replacement value), $L$ is employment (the number

${ }^{11}$ In this analysis we did not take advantage of the panel nature of the 2002 - 2009 BEEPS dataset, for which the female owner variable is available, although the cross-section component is slightly restricted there to only those firms which survived from, or later than, 2005. One further step of the analysis would be to exploit the time dimension of the issue and also to address potential endogeneity issues by using lagged values of the variables, as in Muravyev et al. (2009). 
of full-time permanent employees) and $M$ is the intermediate material input; $X$ are various controls, including the access to finance responses and the tenure of the senior manager in his or her sector (the number of years in the particular field of specialization), as a proxy for the acquired skill via on-the-job learning; and $Z$ is a set of industry and country-level fixed effects.

According to Hypotheses $2 \mathrm{a}$ and $2 \mathrm{~b}$, we expect the coefficients on $F O$ and $F M$ in the regression to be positive. The results of the OLS estimation with heteroskedasticity-robust standard errors for sales are presented in Table $4 .^{12}$

\section{[Insert Table 4 Here.]}

In agreement with earlier findings for the same geopolitical region (Sabarwal and Terrell, 2008), without controlling for the access to external finance we find that, on average, firms owned or managed by females have lower sales, although the significance is not robust to the inclusion of other controls (Table 4, columns 1, 2, 4, and 5). However, when we introduce the interaction between the female owner and the female senior manager, $F O \times F M$, the coefficients on both the female owner and the female senior manager variables become positive and significant at the 0.01 level, whereas the coefficient on the interaction variable is negative and significant at the 0.01 level (columns 3 and 6$)$. This result remains robust for $F M$ and $F O \times F M$ in all specifications, and for $F O$ in almost all specification, both in significance and sign, when we add controls for inputs and controls for the access to external finance. If the positive effect of the female owner and of the female manager is due to their higher entrepreneurial skill, as the theoretical model predicts, the negative coefficient on the interaction variable suggests that the positive effect of a female manager is stronger in firms owned by men than in

\footnotetext{
${ }^{12}$ We also estimated two alternative versions of the model, with (the logarithm of) profits and with (the logarithm of) profits per unit of sales as the dependent variable. (In the second specification the logarithm of sales was used instead of the logarithms of inputs in the right-hand side.) The results were similar but somewhat weaker. The problem with these two specifications is that they suffer from a selection issue, as only the firms with strictly positive profits will be included in the estimation. Therefore, we concentrate on the results for sales.
} 
firms owned by women. This can be interpreted as some sort of decreasing returns to skill; an alternative explanation is the positive effect of complementarity between female and male styles of leadership in running business. This effect could also be evidence of gender bias in the managerial labour market: to become a manager in a male-owned firm a woman must demonstrate an even higher managerial skill relative to female managers in female-owned firms.

In the industries with preferred female leadership we expect to see a lesser effect of skill difference, because of the additional factor of selection, or self-selection, into the job. To account for this effect we introduce a binary variable, IFM=1 for those industries where female leadership and management may be preferred by owners of both genders (such as food, garments, hospitality, and other services) because of the higher proportion of women employees. We expect the coefficient on the interaction variable, IFM $\times F M$, to be negative, and this is confirmed by the results presented in column 11 of Table 4 . That is, to become a manager in a non-female dominated industry a woman must demonstrate an even higher skill level than female managers in female-dominated industries.

Our model assumed that men and women have identical career opportunities in the labour market and make choices based on relative financial advantages, according to their (unobserved) skill. While this assumption might seem debatable, given different experiences of men and women in the labour market even in the developed Western economies, it can be argued that under the Soviet regime the levels of female employment and the societal expectations about female achievements in the labour market were extremely high. Thus, we expect that women hired under the Soviet regime were more likely to be treated equally to men and hence their occupational choice would less likely to have been distorted. We empirically explore possible effect of the Soviet legacy in gender equality by introducing a binary variable, SovTen=1 if the senior manager has started at this job before 1992 (before the collapse of the Soviet system). However, we did not find any significant effect of this variable nor of the interaction between this variable and the gender variables in the regression, and our main results held well.

We must note that the OLS estimation procedure can potentially suffer from the endogeneity in the input mix chosen by a firm (see Commander and Svejnar, 2011); an often used procedure to correct 
for endogeneity is the use of instrumental variables. Since material inputs is a "noisier" variable than capital and labour inputs, we exclude the material inputs and instrument the other two inputs, following Commander and Svejnar (2011), by the share of workers with higher education, the age of the firm, and the interaction variables of the firm's location (city) and firm age. We also instrument two binary variables describing the access to finance ("Interest rate is too high" and "Collateral too high", cited as obstacles to obtaining a loan) with their averages across all firms except for the given firm, by country, industry and firm size. All these instruments have passed the validity test.

The results of the TSLS estimation for the sales equation are presented in Table 4, column 12; heteroskedasticity-corrected standard errors were used. One can see that the TSLS estimates are fairly close to the OLS estimates in signs, magnitudes and significance.

Finally, we estimated the model for two separate subsamples, small and medium enterprises (250 or less employees, according to the EU classification, 5462 observations) and large firms (over 250 employees, 470 observations). The results are available from the authors upon request. For the SME sub-sample the results are virtually the same as for the entire sample, whereas for the large firms the results are substantially weaker: all the coefficients on the gender variables are insignificant, except for the significant positive coefficient on IFMxFM. This could be explained by different investment and hiring strategies of large firms or by the relatively small number of firms in this category that are managed by females (about 10 per cent of the sub-sample). The TSLS results for the SMEs sample are very similar, with a minor exception of the effect of the female senior manager now having a lower significance.

Overall, consistent with the predictions of our theoretical model, the estimated positive effect of the female gender of senior manager on business performance is significant and robust to the regression specification, whereas the evidence of the positive effect of the female gender of business owner is somewhat weaker. Our results are agree with Coleman (2007) who finds that women-owned firms have significantly higher annual sales growth than firms owned by men if industry and firm size are controlled for.

\subsubsection{Gender Effect on Business Performance: PSM/ATT Estimation}


To address the potential endogeneity and to assess further the robustness of our empirical results, we estimate the average treatment-on-treated (ATT) effect using the propensity score matching (PSM) technique. The technique is described in detail, for example, in Rosenbaum and Rubin (1983, 1985), Heckman et al. (1997), and Becker and Ichino (2002). In general, this technique allows identifying the effect of a specific factor (gender) on the outcome (business performance) by matching individual units (firms) in the data set on all other factors and comparing the outcomes. ${ }^{13}$

To ensure a better comparability we use, first, the whole sample and, second, a sub-sample of SMEs, and estimate the effect of the gender of the senior manager separately for the male-owned and female-owned firms, where the firms with female senior manager are the treated group, and those with male senior manager are the control group.

In our model specification the estimated ATT effect shows the percentage difference in sales between the firms with female senior manager and those with male senior manager. In the probit equation, male and female senior managers are matched on such characteristics as industry, country, labour and capital inputs, instrumented by the sample averages of the constraints on access to finance and of the manager's tenure in his or her area of specialization. ${ }^{14}$ The results of the probit equation are presented in Table 5.

\section{[Insert Table 5 Here.]}

The common support condition, requiring the distributions of the observable characteristics to overlap sufficiently for male and female senior managers, which is necessary for implementing the PSM, is almost fully satisfied in our sample, as shown in Table 5, with all but one observation out of 3023

${ }^{13}$ Sabarwal and Terrell (2008) applied the PSM technique to the 2002 and 2005 waves of the BEEPS data to estimate the ATT effect of female ownership of a firm on the total factor productivity. ${ }^{14}$ We use the psmatch2 command in STATA10 (see, e.g., Kaiser and Malchow-Møller (2011) for the description of the procedure) with kernel matching (Epanechnikov kernel with bandwidth of 0.06) and one-to-one matching (single nearest neighbour with replacement). The two methods produced very similar results. 
within the support in the equation for the male-owned firms and all observations within the support in the equation for the female-owned firms.

Table 6 presents a comparison of the ATT effect obtained from PSM to that from the OLS and the TSLS regressions for the SMEs. The results of the PSM estimation are consistent with our linear regression results. In particular, the ATT effect obtained using kernel matching in the sub-sample of the male-owned firms is 32 percent and is significant at the 0.1 level (the estimated effect is 44 percent when using one-to-one matching, and in the untreated sample the effect is 77 percent). The linear regressions give a robust positive and significant effect, ranging between 20 and 48 per cent, depending on the specification. The TSLS regression with capital and labour inputs, as well as the access to finance constraints, for the SME sub-sample gives an effect of 41 per cent, which is only marginally significant, but for the full sample the estimated effect is 61 per cent, significant at the 0.1 level. We also perform the PSM on the sub-sample of female-owned firms. The estimated ATT effect is negative $(-14$ per cent for the SME sub-samples and -16 per cent for all firms) but statistically insignificant. This, again, agrees with the least squares results indicating a weaker gender effect when both the owner and the senior manager are women, - possibly, as suggested in the previous section, because a woman has to demonstrate higher skill in order to become a senior manager in a firm owned by a man, compare to a firm owned by a woman.

\section{[Insert Table 6 here.]}

\section{CONCLUSION}

According to The Fawcett Society (2013), "companies with more women on their boards were found to outperform their rivals with a 42 percent higher return in sales, 66 percent higher return on invested capital and 53 per cent higher return on equity." This raises a number of questions that are subject of current academic and policy debate. What influences the choice between becoming an entrepreneur versus taking up a paid job, and to what extent is this choice affected by the discrimination in the capital market? Are women more successful in business than men in identical circumstances? If yes, is the reason behind this difference the fact that in a discriminating world a woman must have entrepreneurial skills superior to that of a man in order to achieve the same level of indicators of 
business performance? Does this pattern differ across countries with different institutions and regulations, and at different stages of development?

In order to address some of these questions we have constructed a theoretical model where lenders' discrimination against female entrepreneurs results in a distorted occupational choice. An unequal access to finance leads to different distributions of entrepreneurial skill for men and women conditional on the choice of owning a business or entering paid high-skilled employment, such as a managerial job. In the pool of potential entrepreneurs the marginal woman owner/manager has higher entrepreneurial skill than the marginal man owner/manager. Therefore, the conditional average entrepreneurial skill of women business owners and women managers is higher than that of their male counterparts. If entrepreneurial skill contributes to the business success, then in the identical circumstances firms owned or run by women should perform better than the firms owned or run by men.

Our empirical findings support these model predictions. We find evidence in the data of discrimination of female entrepreneurs in the capital market. After controlling for the usual factors that determine business performance, including access to finance (captured by prohibitively high interest rates and the size of the collateral), the firms with female owners and/or female top managers perform better than the firms with male owners and/or male top managers. We estimate the effect using various econometric techniques and establish a robust empirical result: when controlling for the negative effect of the restricted access to finance, the effects of a female owner and of female senior manager are positive and significant. If the owner's or the manager's entrepreneurial skill is responsible for unobserved heterogeneity in firms' performance, this suggests that female business owners and senior managers tend to have, on average, higher entrepreneurial skills than their male counterparts, as predicted by our theoretical analysis.

Our findings suggest that, indeed, in the countries of the post-Soviet economic space women entrepreneurs need to demonstrate higher skill than men in order to achieve the same career success, and that a masked discrimination in the capital market might be behind the distortion of occupational choice and waste of talent. Policies in these countries should be directed towards monitoring equality 
and elimination of open and hidden gender discrimination to allow aspiring female entrepreneurs fully realize their potential.

\section{References}

Aidis R., Welter F., Smallbone D. \& Isakova, N. (2007). Female entrepreneurship in transition economies: The case of Lithuania and Ukraine. Feminist Economics, 13, 57-83.

Arrow, K.J. (1973). The theory of discrimination. In: O. Ashenfelter and A. Rees (Eds.), Discrimination in Labor Markets (pp. 3-33). Princeton, NJ: Princeton University Press.

Babaeva, L.V. \& Chirikova, A.E. (1996). Women in business. Sociology Research, 3, 75-81. (In Russian.)

Becker, G. (1971) The economics of discrimination. Chicago: University of Chicago Press. Becker, S.O. \& Ichino, A. (2002). Estimation of average treatment effects based on propensity scores. The Stata Journal, 2, 358-377.

Bellucci, A., Borisov, A. \& Zazzaro, A. (2010). Does gender matter in bank-firm relationships? Evidence from small business lending. Journal of Banking and Finance, 34, 2968-2984.

Blanchflower, D.G., Levine, P.B. \& Zimmerman, D.J. (2003). Discrimination in the small-business credit market. Review of Economics and Statistics, 85, 930-943.

Bosma, N., van Praag, M., Thurik, R. \& de Vit, G. (2004). The value of human and social capital investments for the business performance of start-ups. Small Business Economics, 23, 227-236.

Bruton, G.D., Ahlstrom, D. \& Obloj, K. (2008). Entrepreneurship in emerging economies: Where are we today and where should the research go in the future. Entrepreneurship: Theory and Practice, 32, 1-14. Buttner, E.H. \& Rosen, B. (1988) Bank loan officers' perceptions of the characteristics of men, women, and successful entrepreneurs. Journal of Business Venturing, 3, 249-258.

Carter, S., Shaw, E., Lam, W. \& Wilson F. (2007). Gender, entrepreneurship, and bank lending: The criteria and processes used by bank loan officers in assessing applications. Entrepreneurship: Theory and Practice,31, 427-444. 
Center for Study of Public Opinion (2003). 2003 Survey, conducted in Kazakhstan, Kyrgyzstan, Tajikistan, Turkmenistan, and Uzbekistan. USAID.

Chaganti, R. \& Parasuraman, S. (1996). "A Study of the Impacts of Gender on Business Performance and Management Patterns in Small Businesses." Entrepreneurship: Theory and Practice, 21, 73-95. Coate, S. \& Loury, G.S. (1993). Will affirmative-action policies eliminate negative stereotypes? American Economic Review, 83, 220-240.

Coate, S. \& Tennyson, S. (1992). Labor market discrimination, imperfect information and selfemployment. Oxford Economic Papers, 44, 272-288.

Coleman, S. (2000). Access to capital and terms of credit: A comparison of men- and women-owned small businesses. Journal of Small Business Management, 38, 37-52.

Coleman, S. (2007). The role of human and financial capital in the profitability and growth of womenowned small firms. Journal of Small Business Management, 45, 303-319.

Commander, S.J. \& Svejnar, J. (2011). Business environment, exports, ownership, and firm performance. Review of Economics and Statistics, 93, 309-337.

Croson, R. \& Gneezy, U. (2009). Gender differences in preferences. Journal of Economic Literature, 47, $1-27$.

Equality and Human Rights Commission (2011). Sex and Power 2011 Report. Available online at: http://www.equalityhumanrights.com/about-us/our-work/key-projects/sex-and-power Estrin, S. \& Mickiewicz, T. (2011). Institutions and female entrepreneurship. Small Business Economics, $37,397-415$.

Fairlie, R.W. \& Robb, A.M. (2009). Gender differences in business performance: Evidence from the characteristics of business owners survey. Small Business Economics, 33, 375-395.

Fraser, S. (2009). Is there ethnic discrimination in the UK market for small business credit? International Small Business Journal, 27, 583-607.

Fawcett Society (2013). Stats and Facts on Women in Power, 28th Feb 2013.

http://uat.fawcettsociety.org.uk/stats-and-facts-on-women-in-power/ (accessed on 17/05/2015) 
Gneezy, U., Niederly, M. \& Rustichini, A. (2003). Performance in competitive environments: Gender differences. Quarterly Journal of Economics, 68, 1049-1074.

Heckman, J., Ichimura, H. \& Todd, P. (1997). Matching as an econometric evaluation estimator:

Evidence from evaluating a job training programme. Review of Economic Studies, 65, 261-294.

Isakova, N., Kavunenko, L., Welter, F., \& Smallbound, D. (2004). Female entrepreneurs in the Ukraine:

A road to business. Sociology: Theory, Methods, Marketing, 2,146-155. (In Russian.)

Johnsen, G.J. \& McMahon R.G. (2005). Owner-manager gender, financial performance and business growth amongst SMEs from Australia's Business Longitudinal Survey. International Small Business Journal, 23, 115-142.

Jianakoplos, N.A. \& Bernasek A. (2007). Are women more risk averse? Economic Inquiry, 36, 620-630. Kaiser, U. \& Malchow-Møller N. (2011). Is self-employment really a bad experience? The effects of previous self-employment on subsequent wage-employment wages. Journal of Business Venturing, 26, 572-588.

Katz, K. (1997). Gender, wages and discrimination in the USSR: A study of a Russian industrial town. Cambridge Journal of Economics, 21, 431-452.

Kepler, E. \& Shane, S. (2007). Are male and female entrepreneurs really that different? Economic Research Working Paper No. 309 United States Small Business Administration, Office of Advocacy, Washington, D.C.

Lavrinenko, N., \& Rudik, A. (2010). The gender aspect of the development of small businesses." Sociology: Theory, Methods, Marketing, 3, 111-135. (In Russian.)

Lechner, M. (2001). Identification and estimation of causal effects of multiple treatments under the conditional independence assumption. In: M. Lechner and F. Pfeiffer (Eds.) Econometric Evaluation of Labour Market Policies (pp. 1-18). Heidelberg: Physica-Verlag.

Marlow, S. \& McAdam, M. (2013). Gender and entrepreneurship: advancing debate and challenging myths; exploring the mystery of the under-performing female entrepreneur. International Journal of Entrepreneurial Behavior \& Research, 19, 114-124. 
Marlow, S. \& Patton, D. (2005). All credit to men? Entrepreneurship, finance, and gender. Entrepreneurship: Theory and Practice, 29, 717-735.

Moro, A, Fink, M \& Kautonen, T. (2014). How do banks assess entrepreneurial competence? The role of voluntary information disclosure. International Small Business Journal, 32, 525-544.

Muravyev, A., Talavera, O. \& Schäfer, D. (2009). Entrepreneurs' gender and financial constraints:

Evidence from international data. Journal of Comparative Economics, 37, 270-286.

Phelps, E.S. (1972). The statistical theory of racism and sexism. American Economic Review, 62, 659661.

Powell, G. \& Eddleston, K. (2008). The paradox of the contented female business owner. Journal of Vocational Behavior, 73, 24-36.

Rahimova, N.H. (2006).Women and entrepreneurship in Uzbekistan. Public Opinion Monitor, 2, 134139. (In Russian.)

Robb, A. \& Watson, J. (2012). Gender differences in firm performance: Evidence from new ventures in the United States. Journal of Business Venturing, 27, 544-558.

Robb, A. \& Wolken, J.D. (2002). Firm, owner, and financing characteristics: Differences between female- and male-owned small businesses." Board of Governors Finance and Economics Discussion Series 2002-18. Washington, D.C.

Roper, S. \& Scott, J.M. (2009). Perceived financial barriers and the start-up decision: An econometric analysis of gender differences using GEM data. International Small Business Journal, 27, 149-171. Rosenbaum, P. \& Rubin, D. (1983). The central role of the propensity score in observational studies for causal effects. Biometrika, 70, 41-50.

Rosenbaum, P. \& Rubin, D. (1985). Constructing a control group using multivariate matched sampling methods that incorporate the propensity score. The American Statistician, 39, 33-38.

Sabarwal, S. \& Terrell, K. (2008). Does gender matter for firm performance? Evidence from Eastern Europe and Central Asia. Gender and Development Group Policy Research Working Paper No. 4705. The World Bank Poverty Reduction and Economic Management Network, Washington, D.C. 
Scalera, D. \& Zazzaro, A. (2001). Group reputation and persistent (or permanent) discrimination in credit markets. Journal of Multinational Financial Management, 11, 483-496.

Shaffer, M., Joplin, J., Bell, M., Lau, T., \& Oguz, C. (2000). Gender discrimination and job-related outcomes: A cross-cultural comparison of working women in the United States and China. Journal of Vocational Behavior, 57, 395-427.

Smallbone, D. \& Welter, F. (2001a). The distinctiveness of entrepreneurship in transition economies. Small Business Economics, 16, 249-262.

Smallbone, D. \& Welter, F. (2001b). The role of government in SME development in transition economies. International Small Business Journal, 19, 63-77.

Sugarova, F.B. (2012) An assessment of the situation in female entrepreneurship in the republic of Uzbekistan. Current Issues in Humanities and Social Sciences, 2, 119-122. (In Russian.)

Verheul, I. \& Thurik, R. (2001). Start-up capital: Does gender matter? Small Business Economics, 16, 329-346.

Watson, J. (2002). Comparing the performance of male- and female- controlled businesses: Relating outputs to inputs. Entrepreneurship: Theory and Practice, 26, 91-100.

Welter, F. (2011). Contextualizing entrepreneurship - conceptual challenges and ways forward. Entrepreneurship: Theory and Practice, 35, 165-184.

Wu, A. \& Chua, J. H. (2012). Second order gender effects: The case of U.S. small business borrowing cost. Entrepreneurship: Theory and Practice, 36, 443-463. 
Fig. 1. Equilibrium in the capital market and occupational choice.

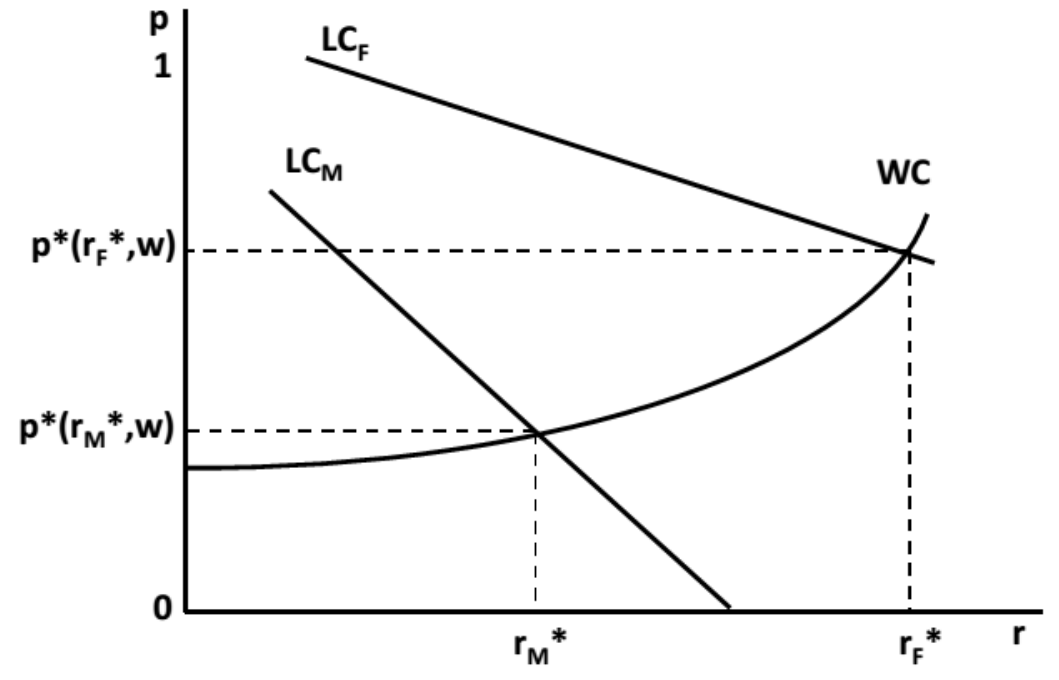

Table 1. Financing of a start-up in Russia. (Source: Babaeva and Chirikova, 1996.)

\begin{tabular}{|c|c|c|c|c|}
\hline & \multicolumn{2}{|c|}{ Women } & \multicolumn{2}{|c|}{ Men } \\
\hline & 1992 & 1993 & 1992 & 1993 \\
\hline & \multicolumn{2}{|c|}{$\%$} & \multicolumn{2}{|c|}{$\%$} \\
\hline Used personal savings & 59 & 36 & 47 & 51 \\
\hline Found an investor & 18 & 10 & 21 & 24 \\
\hline Obtained a credit & 23 & 54 & 32 & 25 \\
\hline
\end{tabular}




\section{Table 2. Summary statistics.}

2.a. Sample means and standard deviations

\begin{tabular}{|c|c|c|c|c|c|c|c|c|c|c|c|c|c|c|c|}
\hline \multirow[t]{2}{*}{ Var } & \multicolumn{3}{|c|}{ All firms } & \multicolumn{3}{|c|}{ Female Owner } & \multicolumn{3}{|c|}{ Male Owner } & \multicolumn{3}{|c|}{ Female Senior Manager } & \multicolumn{3}{|c|}{ Male Senior Manager } \\
\hline & $\mathbf{N}$ & Mean & SD & $\mathbf{N}$ & Mean & SD & $\mathbf{N}$ & Mean & SD & $\mathbf{N}$ & Mean & SD & $\mathbf{N}$ & Mean & SD \\
\hline Sales (\$US) & 7086 & $2.56 \mathrm{E}+07$ & $9.49 \mathrm{E}+08$ & 2926 & $4.12 \mathrm{E}+07$ & $1.47 \mathrm{E}+09$ & 4029 & $1.27 \mathrm{E}+07$ & $1.13 \mathrm{E}+08$ & 1455 & $1.55 \mathrm{E}+07$ & $1.69 \mathrm{E}+08$ & 5620 & $2.82 \mathrm{E}+07$ & $1.06 \mathrm{E}+09$ \\
\hline $\begin{array}{l}\text { Materials } \\
\text { (\$US) }\end{array}$ & 7542 & $4.86 \mathrm{E}+07$ & $1.58 \mathrm{E}+08$ & 3115 & $3.50 \mathrm{E}+07$ & $8.21 \mathrm{E}+07$ & 4379 & $5.84 \mathrm{E}+07$ & $1.94 \mathrm{E}+08$ & 1621 & $4.42 \mathrm{E}+07$ & $1.27 \mathrm{E}+08$ & 5911 & $4.99 \mathrm{E}+07$ & $1.66 \mathrm{E}+08$ \\
\hline Capital (\$US) & 7101 & $1.08 \mathrm{E}+09$ & $4.37 \mathrm{E}+09$ & 2954 & $2.48 \mathrm{E}+09$ & $6.49 \mathrm{E}+09$ & 4113 & $9.13 \mathrm{E}+07$ & $5.77 \mathrm{E}+08$ & 1536 & $2.64 \mathrm{E}+09$ & $6.83 \mathrm{E}+09$ & 5555 & $6.52 \mathrm{E}+08$ & $3.26 \mathrm{E}+09$ \\
\hline Employment & 10152 & 112.378 & 543.974 & 4021 & 111.732 & 396.581 & 5920 & 97.373 & 330.955 & 2054 & 72.782 & 205.414 & 8085 & 122.571 & 600.282 \\
\hline Tenure & 10152 & 15.874 & 9.892 & 4021 & 16.811 & 10.408 & 5920 & 15.340 & 9.504 & 2054 & 15.555 & 10.158 & 8085 & 15.956 & 9.820 \\
\hline FO & 9941 & 0.404 & 0.491 & & & & & & & 2022 & 0.817 & 0.387 & 7906 & 0.299 & 0.458 \\
\hline FM & 10139 & 0.203 & 0.402 & 4013 & 0.411 & 0.492 & 5915 & 0.063 & 0.242 & & & & & & \\
\hline $\mathrm{FO} \times \mathrm{FM}$ & 9928 & 0.166 & 0.372 & & & & & & & & & & & & \\
\hline IFM & 10152 & 0.324 & 0.468 & 4021 & 0.365 & 0.481 & 5920 & 0.298 & 0.457 & 2054 & 0.468 & 0.499 & 8085 & 0.288 & 0.453 \\
\hline FM $\times$ IFM & 10152 & 0.495 & 0.499 & 4021 & 0.559 & 0.496 & 5920 & 0.453 & 0.497 & 2054 & 0.696 & 0.460 & 8085 & 0.444 & 0.496 \\
\hline FO x FM x & & & & & & & & & & & & & & & \\
\hline IFM & 9941 & 0.226 & 0.418 & 4021 & 0.559 & 0.496 & 5920 & 0 & 0 & 2022 & 0.585 & 0.493 & 7906 & 0.134 & 0.341 \\
\hline Int_Rate_high & 9999 & 0.094 & 0.292 & 3973 & 0.097 & 0.296 & 5827 & 0.093 & 0.290 & 2020 & 0.106 & 0.308 & 7966 & 0.091 & 0.287 \\
\hline Collat_High & 9999 & 0.031 & 0.173 & 3973 & 0.036 & 0.186 & 5827 & 0.028 & 0.164 & 2020 & 0.038 & 0.192 & 7966 & 0.029 & 0.168 \\
\hline
\end{tabular}


2.b. Sample correlation coefficients

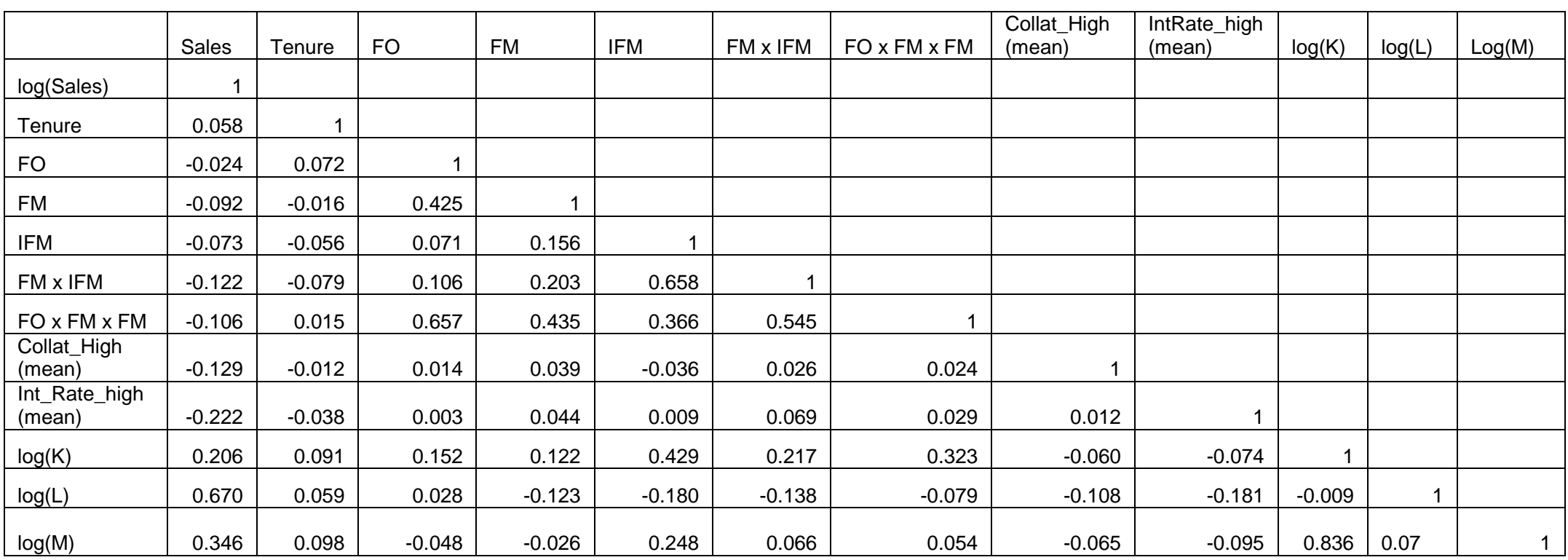

Table 3. Differences in means measuring access to finance.

\begin{tabular}{|c|c|c|c|c|}
\hline Variable & Female Owner & Male Owner & t-stat & $\mathrm{p}$-value \\
\hline Interest rate too high & .0964 & .0928 & -0.6047 & 0.2727 \\
\hline Collateral too high & .0355 & .0271 & -2.4054 & 0.0081 \\
\hline Access to finance as an obstacle & 2.7640 & 2.7240 & -1.8194 & 0.0345 \\
\hline Collateral as \% of loan value & 137.7953 & 132.6266 & -0.7334 & 0.2317 \\
\hline
\end{tabular}


Table 4. Summary of $\log ($ Sales) regression, all firms.

\begin{tabular}{|c|c|c|c|c|c|c|c|c|c|c|c|c|}
\hline & 1 & 2 & 3 & 4 & 5 & 6 & 7 & 8 & 9 & 10 & 11 & 12 \\
\hline $\log K$ & & & & $\begin{array}{l}-0.073^{*+*+} \\
(0.000)\end{array}$ & $\begin{array}{l}-0.076^{* * *} \\
(0.000)\end{array}$ & $\begin{array}{l}-0.071^{* * *} \\
(0.000)\end{array}$ & & & $\begin{array}{l}-0.071^{\text {t*t* }} \\
(0.000)\end{array}$ & $\begin{array}{l}-0.071^{* * *} \\
(0.000)\end{array}$ & $\begin{array}{l}-0.06^{* * *} \\
(0.000)\end{array}$ & $\begin{array}{l}-0.076^{t+*+} \\
(0.000)\end{array}$ \\
\hline $\log M$ & & & & $\begin{array}{l}0.187^{*+1+} \\
(0.000)\end{array}$ & $\begin{array}{l}0.192^{* * *} \\
(0.000) \\
\end{array}$ & $\begin{array}{l}0.187^{* * *} \\
(0.000)\end{array}$ & & & $\begin{array}{l}0.186^{*+1} \\
(0.000)\end{array}$ & $\begin{array}{l}0.186^{* *+} \\
(0.000)\end{array}$ & $\begin{array}{l}0.18^{*+* t} \\
(0.000)\end{array}$ & $\begin{array}{l}0.212 \\
(0.000)\end{array}$ \\
\hline $\mathrm{FO}$ & $\begin{array}{l}-0.026 \\
(0.591)\end{array}$ & & $\begin{array}{l}0.389^{* * *} \\
(0.000)\end{array}$ & $\begin{array}{l}-0.059^{*} \\
(0.099)\end{array}$ & & $\begin{array}{l}-0.006 \\
(0.872)\end{array}$ & $\begin{array}{l}0.383^{* * *} \\
(0.000)\end{array}$ & $\begin{array}{l}0.383^{* * *} \\
(0.000)\end{array}$ & $\begin{array}{l}-0.004 \\
(0.913)\end{array}$ & $\begin{array}{l}-0.003 \\
(0.947)\end{array}$ & $\begin{array}{l}.095^{*} \\
(0.052)\end{array}$ & $\begin{array}{l}0.137^{2 *} \\
(0.012)\end{array}$ \\
\hline FM & & $\begin{array}{l}-0.504^{* * *} \\
(0.000)\end{array}$ & $\begin{array}{l}0.569^{*+1} \\
(0.000)\end{array}$ & & $\begin{array}{l}-0.051 \\
(0.218) \\
\end{array}$ & $\begin{array}{l}0.202^{* *} \\
(0.015)\end{array}$ & $\begin{array}{l}0.568^{*+2+} \\
(0.000)\end{array}$ & $\begin{array}{l}0.559^{* * *} \\
(0.000)\end{array}$ & $\begin{array}{l}0.209^{*+*} \\
(0.012)\end{array}$ & $\begin{array}{l}0.208^{* *} \\
(0.013)\end{array}$ & $\begin{array}{l}0.219^{*+*+} \\
(0.000)\end{array}$ & $\begin{array}{l}0.271^{* *+} \\
(0.004)\end{array}$ \\
\hline $\mathrm{FO} \times \mathrm{FM}$ & & & $\begin{array}{l}-1.542^{*+*+} \\
(0.000)\end{array}$ & & & $\begin{array}{l}-0.314^{* * *} \\
(0.001) \\
\end{array}$ & $\begin{array}{l}-1.513^{*+*+} \\
(0.000)\end{array}$ & $\begin{array}{l}-1.495^{* * *} \\
(0.000)\end{array}$ & $\begin{array}{l}-0.321^{* \star *} \\
(0.001)\end{array}$ & $\begin{array}{l}-0.319^{* * *} \\
(0.001) \\
\end{array}$ & $\begin{array}{l}-0.321^{*+*+} \\
(0.000)\end{array}$ & $\begin{array}{l}-0.353^{*+\cdots+1} \\
(0.001)\end{array}$ \\
\hline $\begin{array}{l}\text { 'Interest rate } \\
\text { too high' }\end{array}$ & & & & & & & $\begin{array}{l}-0.844^{x+2+} \\
(0.000)\end{array}$ & $\begin{array}{l}-0.888^{* * *} \\
(0.000)\end{array}$ & $\begin{array}{l}-0.312^{* * *} \\
(0.000)\end{array}$ & $\begin{array}{l}-0.327^{* * *} \\
(0.000)\end{array}$ & $\begin{array}{l}-0.328^{*+*} \\
(0.000)\end{array}$ & $\begin{array}{l}-0.314^{*+*} \\
(0.000)\end{array}$ \\
\hline $\begin{array}{l}\text { 'Collateral too } \\
\text { high' }\end{array}$ & & & & & & & & $\begin{array}{l}-1.047^{* * *} \\
(0.000)\end{array}$ & & $\begin{array}{l}-0.302^{* * *} \\
(0.000)\end{array}$ & $\begin{array}{l}-0.306^{* *+} \\
(0.000)\end{array}$ & $\begin{array}{l}-0.289^{*+1+} \\
(0.002)\end{array}$ \\
\hline IFM $x$ FM & & & & & & & & & & & $\begin{array}{l}-0.189^{*} \\
(0.097)\end{array}$ & $\begin{array}{l}-0.186 \\
(0.153) \\
\end{array}$ \\
\hline $\begin{array}{l}\text { IFM x FO x } \\
\text { FM }\end{array}$ & & & & & & & & & & & $\begin{array}{l}-0.187^{\mathrm{ta+1}} \\
(0.01)\end{array}$ & $\begin{array}{l}-0.185^{*+} \\
(0.037)\end{array}$ \\
\hline $\mathrm{N}$ & 7086 & 7208 & 7072 & 6106 & 6128 & 6094 & 6988 & 6988 & 6033 & 6033 & 5932 & 5261 \\
\hline R-sq. & 0.321 & 0.330 & 0.340 & 0.733 & 0.734 & 0.733 & 0.352 & 0.358 & 0.734 & 0.734 & 0.734 & 0.733 \\
\hline $\begin{array}{l}\text { Chi-sq. } \\
\text { (p-value) }\end{array}$ & & & & & & & & & & & & $\begin{array}{l}0.002 \\
(0.967)\end{array}$ \\
\hline
\end{tabular}

Note: $Y=\log ($ Sales $\$$ US), p-values in parentheses; country and industry-level dummies included.

* significant at 0.1 level, ${ }^{* *}$ significant at 0.05 level, ${ }^{* * *}$ significant at 0.01 level 
Table 5. PSM (probit) estimation with kernel matching.

\begin{tabular}{|c|c|c|c|c|}
\hline $\mathrm{Y}=\mathrm{FM}$ & \multicolumn{2}{|c|}{ SME } & \multicolumn{2}{|c|}{ All firms } \\
\hline & Male owner & Female owner & Male owner & Female owner \\
\hline $\log K$ & $\begin{array}{l}-.006 \\
(0.809)\end{array}$ & $\begin{array}{l}-.001 \\
(0.922)\end{array}$ & $\begin{array}{l}-.023 \\
(0.313)\end{array}$ & $\begin{array}{l}.008 \\
(0.581)\end{array}$ \\
\hline $\log L$ & $\begin{array}{l}.109^{\text {t*t }} \\
(0.004)\end{array}$ & $\begin{array}{l}-.279^{\text {tat }} \\
(0.000)\end{array}$ & $\begin{array}{l}.125^{\text {tat }} \\
(0.000)\end{array}$ & $\begin{array}{l}-.251^{\text {tat }} \\
(0.000)\end{array}$ \\
\hline Tenure & $\begin{array}{l}-.019^{*+1+} \\
(0.000)\end{array}$ & $\begin{array}{l}-.002 \\
(0.591) \\
\end{array}$ & $\begin{array}{l}-.015^{\text {tht }} \\
(0.001)\end{array}$ & $\begin{array}{l}-.002 \\
(0.356) \\
\end{array}$ \\
\hline 'Interest rate too high' & $\begin{array}{l}.189 \\
(0.583)\end{array}$ & $\begin{array}{l}.193 \\
(0.477)\end{array}$ & $\begin{array}{l}.19 \\
(0.527)\end{array}$ & $\begin{array}{l}.339 \\
(0.166)\end{array}$ \\
\hline 'Collateral too high' & $\begin{array}{l}.923 \\
(0.119)\end{array}$ & $\begin{array}{l}.522 \\
(0.201)\end{array}$ & $\begin{array}{l}1.096^{*} \\
(0.011)\end{array}$ & $\begin{array}{l}.416 \\
(0.266)\end{array}$ \\
\hline LR & 119.04 & 448.23 & 133.67 & 508.13 \\
\hline $\operatorname{Pr}>x^{2}$ & 0.000 & 0.000 & 0.000 & 0.000 \\
\hline$N$ & 2781 & 2107 & 3023 & 2305 \\
\hline Pseudo $\mathrm{R}^{2}$ & 0.094 & 0.155 & 0.094 & 0.162 \\
\hline
\end{tabular}

Note: $p$-values in parentheses; country and industry-level dummies included.

* significant at 0.1 level, ${ }^{* *}$ significant at 0.05 level, ${ }^{* *}$ significant at 0.01 level

Table 6. Comparison of the OLS and the TSLS estimates with ATT effects from PSM estimation with kernel matching.

\begin{tabular}{|c|c|c|c|c|c|c|c|}
\hline Sample & $\mathrm{N}$ & $\begin{array}{l}\text { Female TM } \\
\text { (Treated) }\end{array}$ & Male TM (Control) & Diff & SE & OLS & TSLS \\
\hline Unmatched, Male owner, SME & 2781 & 14.162 & 13.391 & $0.77^{* *+*}$ & 0.171 & $0.19^{* *}$ & $0.23^{* *}$ \\
\hline ATT, Male owner, SME & 2781 & 14.162 & 13.843 & $0.32^{*}$ & 0.183 & $0.19^{* *}$ & $0.23^{* *}$ \\
\hline ATT, Female owner, SME & 2107 & 12.651 & 12.796 & -0.14 & 0.114 & $-0.12^{* * *}$ & $-0.32^{* * *}$ \\
\hline ATT, Male owner, all firms & 3023 & 14.533 & 14.153 & $0.38^{*+1+}$ & 0.184 & $0.22^{* * *}$ & $0.27^{*+1+}$ \\
\hline ATT, Female owner, all firms & 2305 & 12.804 & 12.961 & -0.16 & 0.117 & $-0.32^{* * *}$ & $-0.35^{* * *}$ \\
\hline
\end{tabular}

Note: Dependent variable: log(Sales); country- and industry- level dummies included. ATT effects computed from PSM estimation

with kernel matching. ${ }^{*}$ significant at 0.1 level, ${ }^{* *}$ significant at 0.05 level, ${ }^{* \star}$ significant at 0.01 level 